\title{
Decrease of faunal diversity in a disturbed lake, as exemplified by Tanytarsini chironomids (Diptera: Chironomidae) of Jezioro Żarnowieckie
}

\author{
Wojciech GILKA* and Weronika PODLESIŃSKA** \\ Department of Invertebrate Zoology, University of Gdańsk, A1. Marszalka Pitsudskiego 46, 81-378 Gdynia, Poland; \\ *e-mail: scorpio@ocean.univ.gda.pl,**e-mail: bbujka@o2.pl
}

\begin{abstract}
Diversity of the Tanytarsini chironomids (Diptera: Chironomidae) collected on the Zarnowieckie Lake (northern Poland) in the early 1980s and in 2008-2009 was compared. The analysis demonstrated a significant impoverishment of the Żarnowieckie chironomid fauna. Within less than 30 years, the number of Tanytarsini species dropped from 21 to 14, and the fauna became dominated by common eurytopic species Cladotanytarsus atridorsum Kieffer (more than $73 \%$ of all individuals collected in 2008), C. mancus (Walker) (more than 8\%), and Paratanytarsus inopertus (Walker) (more than 9\%). The four species rare in Poland [Tanytarsus niger Andersen, Rheotanytarsus muscicola Thienemann, Stempellinella brevis (Edwards), Paratanytarsus tenellulus (Goetghebuer)], recorded in the area in the 1980s, were absent in 2008-2009. The reduction in the Tanytarsini diversity is interpreted as an effect of unstable environmental regime of the lake following its artificial modification in 1983 to serve the needs of the "Zarnowiec" pumped storage power station, and interventions related to the planned construction of a nuclear power plant on the lake.
\end{abstract}

Key words: Diptera, Chironomidae, Tanytarsini, Lake Żarnowieckie, biodiversity

\section{INTRODUCTION}

The Tanytarsini form one of the largest tribes of the family Chironomidae, represented by about 200 species known from Europe, including 105 species recorded in Poland (Sæther \& Spies 2004; Gilka 2006, 2009; Gilka \& Dominiak 2007). The Tanytarsini reproduce primarily in fresh water and inhabit almost all types of freshwater aquatic habitats. A substantial number of species in the tribe and their varying tolerance to destabilising factors affecting their habitats make the Tanytarsini good candidates for indicators in environmental assessment of aquatic habitats.

This paper is a part of series of studies addressing biodiversity and directions of changes in the Tanytarsini fauna of the largest and most important freshwater reservoirs of the Gdańsk Lakeland. Data on the Tanytarsini fauna of the region have been reported in a number of recent publications (Gilka 1997, 2001b, 2001c, 2002, 2009; Gilka \& Dominiak 2007).

Within less than 30 years, the aquatic habitat of the Zarnowieckie Lake changed as a result of human interventions related to the planned construction of a nuclear power plant and due to the ,Żarnowiec" S.A. pumped storage power plant being put into operation in 1983. Materials analysed in this study, collected in the early 1980s and in 2008-2009, made it possible to follow changes in the composition of the Tanytarsini fauna of the Zarnowieckie Lake.

\section{STUDY AREA}

The Żarnowieckie Lake (Fig. 1), Poland's largest and northernmost inland water body $\left(54^{\circ} 46^{\prime} \mathrm{N}, 18^{\circ} 35^{\prime} \mathrm{E}\right)$ originally covered 1443 ha and contained 124 million $\mathrm{m}^{3}$ water at the altitude of $1.50 \mathrm{~m}$ above sea level (as documented by measurements performed in 1960 by the Inland Fisheries Institute in Olsztyn; Wiśniewolski \& Malinowski 2004). In the 1980s, the lake's characteristics changed as a result of interventions associated with power plant construction, which involved burying the south-eastern part of the lake, damming its water, and regulating 
the lake's discharge into the Baltic Sea. Measurements commissioned by the "Żarnowiec" pumped storage power station (Elektrownia Wodna „Żarnowiec", EWŻ) in 2000 showed the lake to cover now $1388 \mathrm{ha}$, with the volume of up to 123.2 million $\mathrm{m}^{3}$, and the mean and maximum depths of 8.4 and $19.4 \mathrm{~m}$, respectively (Wiśniewolski \& Malinowski 2004). EWŻ uses the lake as a source of water and the site of its discharge after pumping; as a consequence, the lake's water is cyclically mixed. The EWŻ operation induces changes in water level of up to $1 \mathrm{~m}$ per day (Dubrawski et al. 2003, Wiśniewolski \& Malinowski 2004).

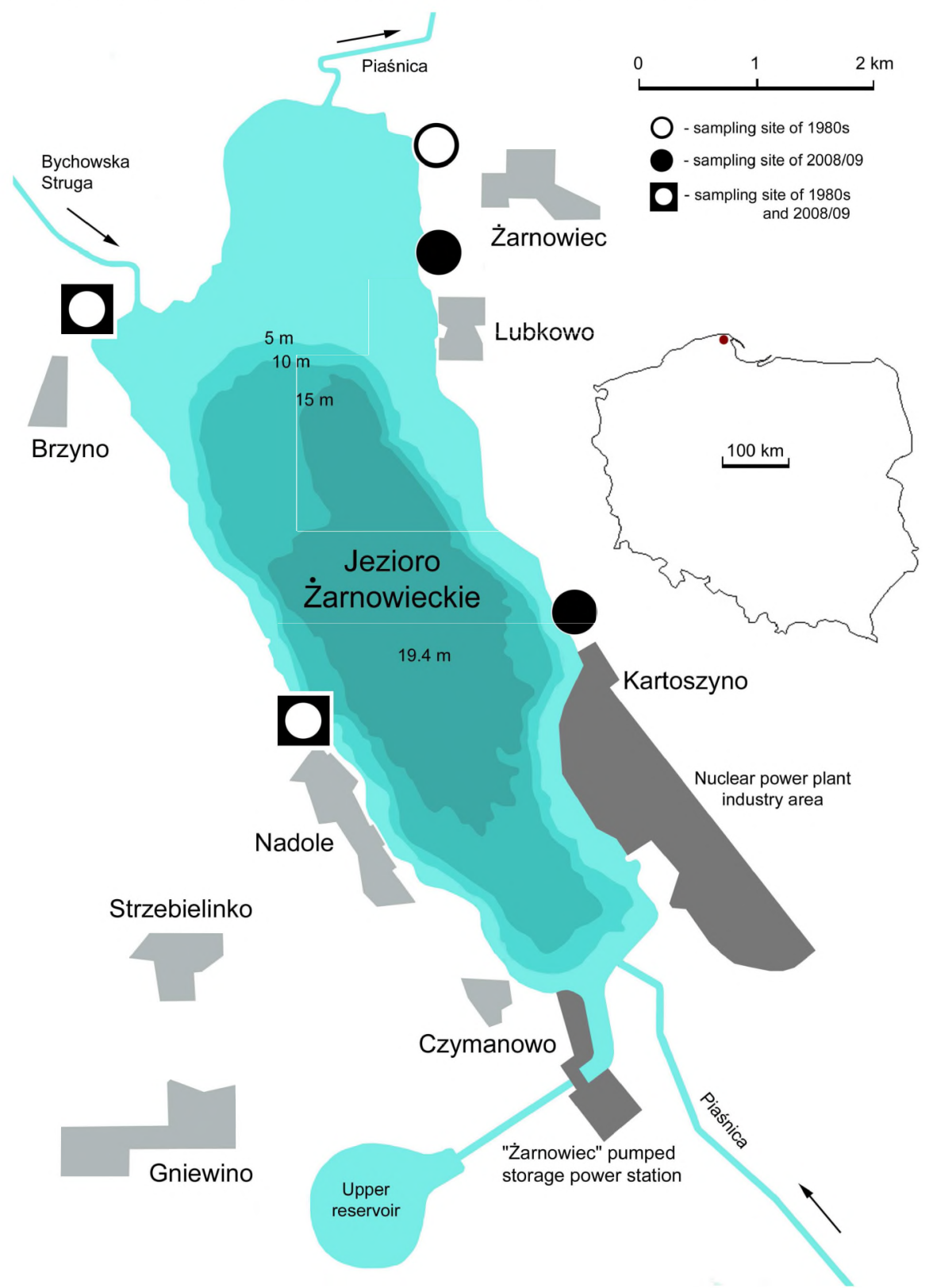

Fig. 1. Study area and distribution of sampling sites. 
The mean annual water temperature in the surface layer is $9^{\circ} \mathrm{C}$, the mean summer temperature amounting to about $18^{\circ} \mathrm{C}$ (Dubrawski et al. 2003). At present, the trophic status of the Żarnowieckie Lake can be described as intermediate between $\beta$ mesotrophic and eutrophic, eutrophication tending to intensify. The entire lake shows very good oxygen regime; however, mechanical and hydrodynamic destruction of the shallow littoral, devoid of water for several hours per day, results in, i.a., changes in the biomass of macrobenthos and macrophytes (Dubrawski et al. 2003). A prolonged stagnation and strong increase in water fertility in the flooding zone, brought about by accumulation of abundant organic matter, results in irreversible changes associated with regressive succession, degradation of plant communities, and complete disappearance of some rare species (Pliński \& Wnorowski 1993).

\section{MATERIALS AND METHODS}

The materials used in this work consisted of a total of 3869 adult males of 25 Tanytarsini species collected in 1980-1983 and 2008-2009. The 1980s collection consisted of 429 chironomid individuals sampled from the three sites near the villages of Brzyno, Nadole and Żarnowiec (15 samples) between April and August. The remaining samples (51) were collected regularly, at least once a month in 2008 (April-November) and at the beginning of 2009 (April) from four sites distributed uniformly around the lake (Brzyno, Kartoszyno, Lubkowo and Nadole) (Fig. 1). The chironomids were captured with a sweep net during swarming or by "mowing" from herbaceous plants, shrubs, and trees near the lake; some individuals were caught with light traps. The sampling methods were the same in 1980s and 2008/2009. The adult males were assigned to species with use of the keys by Lehmann 1970, Reiss \& Fittkau 1971, Säwedal 1976, Reiss \& Säwedal 1981, Giłka 2001a, 2001c, Stur \& Ekrem 2006, Ekrem 2007. The materials collected in 1980-1983 by Professor Ryszard Szadziewski and in 2008 2009 by the junior author are available at the Department of Invertebrate Zoology, University of Gdańsk.

\section{RESULTS}

Tanytarsini collections examined were found to consist of 26 species representing 6 genera (Table 1). The 1980-1983 collection consisted of 429 individuals representing 21 species, whereas the $2008 / 2009$ collection numbered 3440 individuals assigned to 14 species. The $2008 / 2009$ collection contained 9 of the 21 species recorded in 1980-1983; 5 species had not been recorded before, while 12 species present in 1980-1983 were missing. The 2008/2009 collection was dominated by a single species, Cladotanytarsus atridorsum Kieffer, which accounted for more than $73 \%$ individuals and was present in all samples collected in 2008 (except in April) from all sites (Tables 1 \& 2).

Adult Tanytarsini were present on the Zarnowieckie Lake as of April. The first to appear were individuals representing species of the genera Micropsectra and Tanytarsus, including the early-spring single-generation Tanytarsus sylvaticus. The highest number of individuals was collected in May, whereas the highest number of species was recorded in September. In the 2008 season, the last sample, consisting of male Cladotanytarsus atridorsum, C. mancus and M. atrofasciata, was collected on November, 12th (Table 2).

\section{DISCUSSION}

The species recorded on the Żarnowieckie Lake account for slightly more than $25 \%$ of the Polish Tanytarsini fauna. Considering the size of the study area, the number of the species found should be regarded as relatively low. A total of 33 species were found on the Radunskie lakes (an area of a comparable size) (Gilka \& Dominiak 2007). 
Table 1. Numbers of individuals of Tanytarsini (n) and the percentage (\%) of species recorded on the Żarnowieckie Lake.

\begin{tabular}{|c|c|c|c|c|c|c|}
\hline Sampling period & \multicolumn{2}{|c|}{$1980-1983$} & \multicolumn{2}{|c|}{$2008-2009$} & \multicolumn{2}{|c|}{$1980-2009$} \\
\hline Species & $\mathrm{n}$ & $\%$ & $\mathrm{n}$ & $\%$ & $\mathrm{n}$ & $\%$ \\
\hline C. atridorsum Kieffer & 43 & 10.02 & 2523 & 73.34 & 2566 & 66.06 \\
\hline C. mancus (Walker) & 31 & 7.23 & 291 & 8.46 & 322 & 8.32 \\
\hline M. apposita (Walker) & - & 0 & 8 & 0.23 & 8 & 0.21 \\
\hline M. atrofasciata (Kieffer) & 10 & 2.33 & 90 & 2.62 & 100 & 2.58 \\
\hline M. junci(Meigen) & - & 0 & 14 & 0.41 & 14 & 0.36 \\
\hline$M$. notescens (Walker) & - & 0 & 3 & 0.09 & 3 & 0.08 \\
\hline M. recurvata Goetghebuer & 1 & 0.23 & - & 0 & 1 & 0.03 \\
\hline P. inopertus (Walker) & 24 & 5.59 & 322 & 9.36 & 346 & 8.94 \\
\hline P. laccophilus (Edwards) & - & 0 & 1 & 0.03 & 1 & 0.03 \\
\hline P. lauterborni (Kieffer) & 1 & 0.23 & - & 0 & 1 & 0.03 \\
\hline P. tenellulus (Goetghebuer) & 14 & 3.26 & - & 0 & 14 & 0.36 \\
\hline$P$. tenuis (Meigen) & 1 & 0.23 & - & 0 & 1 & 0.03 \\
\hline R. muscicola Thienemann & 3 & 0.70 & - & 0 & 3 & 0.08 \\
\hline S. brevis (Edwards) & 1 & 0.23 & - & 0 & 1 & 0.03 \\
\hline T. bathophilus Kieffer & 10 & 2.33 & 15 & 0.44 & 25 & 0.65 \\
\hline T. brundini Lindeberg & 32 & 7.46 & 2 & 0.06 & 34 & 0.88 \\
\hline T. dibranchius Kieffer & 1 & 0.23 & - & 0 & 1 & 0.03 \\
\hline T. lestagei Goetghebuer & 23 & 5.36 & 5 & 0.15 & 28 & 0.72 \\
\hline T. ex gr. lestagei & 14 & 3.26 & - & 0 & 14 & 0.36 \\
\hline T. mendax Kieffer & 2 & 0.47 & - & 0 & 2 & 0.05 \\
\hline T. niger Andersen & 1 & 0.23 & - & 0 & 1 & 0.03 \\
\hline T. pallidicornis (Walker) & 8 & 1.86 & 66 & 1.92 & 74 & 1.91 \\
\hline T. sylvaticus (van der Wulp) & - & 0 & 76 & 2.21 & 76 & 1.96 \\
\hline T. usmaensis Pagast & 2 & 0.47 & - & 0 & 2 & 0.05 \\
\hline T. verralli Goetghebuer & 206 & 48.02 & 24 & 0.70 & 230 & 5.94 \\
\hline T. volgensis Miseiko & 1 & 0.23 & - & 0 & 1 & 0.03 \\
\hline Total & 429 & $100 \%$ & 3440 & $100 \%$ & 3869 & $100 \%$ \\
\hline Number of species & \multicolumn{2}{|c|}{21} & \multicolumn{2}{|c|}{14} & \multicolumn{2}{|c|}{26} \\
\hline
\end{tabular}

The Tanytarsini fauna of both areas differs substantially, Jaccard's faunistic similarity index being as low as $37 \%$. Margalef's diversity index for the Raduńskie Tanytarsini was as high as 3.79 , in contrast to the values 3.13 and 1.35 that were found on the Żarnowieckie Lake in 1980-1983 and 2008, respectively. Even if one takes into account the dependence of the index on the number of individuals, the difference in values of the index is considerable and it shows that the Tanytarsini fauna of the Żarnowieckie Lake become impoverished.

The experiences with the Zarnowieckie Lake point the changes in trophic status as a consequence of sewage discharge inflow, i.e. from the discharge of sewage treatment plant collector at Nadole and from untreated sewage discharge from the village of Lubkowo (the village without a treatment plant). The power station's operation generates water currents and induces cyclic mixing of the entire water volume in the lake. Consequently, water of the upper pelagial and the littoral (down to $5 \mathrm{~m}$ depth) is oxygen-saturated. On the other hand, processes taking place in the shallow littoral are typical for eutrophic water bodies. Under such unstable conditions, it is mainly the eurytopic species that are able to develop and persist (Table 1). Almost $84 \%$ of the specimens caught in 2008 represent two Cladotanytarsus species, common in Poland and tolerant of heavily eutrophic lentic water bodies.

The Tanytarsini fauna of the Żarnowieckie Lake comprised some species that are seldom observed in Poland: Tanytarsus niger Andersen, so far known from the single site in Poland (Gilka 2002); Rheotanytarsus muscicola Thienemann, found - in addition to the Żarnowieckie Lake - at three sites in Cracow (Lehmann 1970), in the Masurian Lakeland and in the Bieszczady Mountains (Giłka 2002); Stempellinella brevis (Edwards), known from the Jura KrakowskoCzęstochowska region (Gilka 2002) and from three dubious identifications based on larvae collected in the Pieniny Mountains (Kownacki 1982), on the Babia Gora Mountain (Dratnal 1970) 
and in the Beskidy Mountains (Sowa 1965); Paratanytarsus tenellulus (Goetghebuer), recorded in the Masurian (4 sites) and Kashubian (1 site) Lakelands (Gilka 2002); and Paratanytarsus laccophilus (Edwards), so far reported from two sites in the Masurian Lakeland (Gilka 2002) and from a single site in the Tatra Mountains (Gilka 2007). The species mentioned above were recorded in Brzyno and Nadole, except for P. laccophilus collected in Lubkowo. Unfortunately, four of the five species listed (except for P. laccophilus) were not found in 2008-2009.

Table 2. Numbers of individuals and species of the Tanytarsini ccollected in different months of the year 2008 on the Żarnowieckie Lake.

\begin{tabular}{|c|c|c|c|c|c|c|c|c|}
\hline Species $\backslash$ month & April & May & June & July & Aug & Sep & Oct & Nov \\
\hline C. atridorsum & - & 1254 & 691 & 190 & 188 & 158 & 21 & 21 \\
\hline C. mancus & - & 149 & 12 & 7 & 33 & 81 & 8 & 1 \\
\hline M. apposita & 3 & - & - & - & - & 2 & 1 & - \\
\hline M. atrofasciata & 8 & - & - & - & - & 1 & 48 & 16 \\
\hline P. inopertus & - & 1 & - & 73 & 83 & 165 & - & - \\
\hline P. laccophilus & - & - & - & - & - & 1 & - & - \\
\hline T. bathophilus & 6 & - & - & - & - & - & 9 & - \\
\hline T. brundini & - & - & - & - & - & 1 & 1 & - \\
\hline T. lestagei & - & - & - & - & 1 & 4 & - & - \\
\hline T. pallidicornis & 13 & - & - & - & 7 & 31 & 2 & - \\
\hline T. sylvaticus & 41 & - & - & - & - & - & - & - \\
\hline T. verralli & 3 & 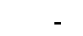 & _ & - & 7 & 14 & - & - \\
\hline Total & 74 & 1404 & 703 & 270 & 319 & 458 & 90 & 38 \\
\hline Number of species & 6 & 3 & 2 & 3 & 6 & 10 & 7 & 3 \\
\hline
\end{tabular}

The pattern of seasonal dynamics of appearance of the adult Tanytarsini was distinctly different than these described earlier for the Tanytarsini of the Kashubian Lakeland (Gilka \& Dominiak 2007) and entire Poland (Gilka 2002) with 4 or 5 peaks of appearance: early and late spring, summer, late summer and autumn, lasting until the second decade of October. As few as two marked peaks of abundance and species richness were observed in the Zarnowieckie Tanytarsini fauna in 2008: one in April-May and the other in September-October (Table 2). Interestingly, the adult males of Cladotanytarsus atridorsum, C. mancus, and Micropsectra atrofasciata were observed to form swarms as late as in early November.

The non-typical pattern of the dynamics of appearance was, doubtless, influenced by intensive mixing of the entire water volume of the lake, cyclic changes in water level, and drying out of a part of the shallow littoral.

\section{ACKNOWLEDGEMENTS}

We wish to express gratitude to Professor Ryszard Szadziewski for providing access to his collection. We are grateful to the staff of the Elektrownia Wodna "Żarnowiec" S.A. for supplying us with documentation on the Lake Żarnowieckie. The junior author would like to thank Ewa and Jacek Podlesiński for assistance in collecting the samples.

\section{REFERENCES}

DRATNAL E. 1970. Materialy do poznania ochotkowatych (Chironomidae, Diptera) Babiogórskiego Parku Narodowego i okolic. Ochrona Przyrody 35: 269-280.

DUBRAWSKI R., JACKOWSKI E. \& KRUK-DOWGIAŁLO L. 2003. Oddziaływania elektrowni wodnej Żarnowiec S.A. na ekosystem Jeziora Żarnowieckiego ze szczególnym uwzględnieniem wpływu na ichtiofaunę oraz program zagospodarowania rybackiego zbiornika [Opinion]. Elektrownia Wodna Żarnowiee S.A., Czymanów, 43 pp.

EKREM T. 2007. A taxonomic revision of the genus Stempellinella (Diptera: Chironomidae). Journal of Natural History 41: 1367-1465.

GÆKA W. 1997. Cladotanytarsus teres in Poland (Diptera: Chironomidae). Polish Journal of Entomology 66: 271-276. GÆKA W. 2001a. A description of Micropsectra rilensis sp. n. (Diptera: Chironomidae) with a review of Bulgarian Tanytarsini. Polish Journal of Entomology 70: 65-72. 
GÆKA W. $200 \mathrm{lb}$. Seasonal dynamic of some chironomids of the tribe Tanytarsini in the Kashubian Lakeland (Diptera: Chironomidae). Acta entomologica silesiana 7-8: 31-42. [In Polish with English abstract]

GEKA W. 2001c. A review of Polish Cladotanytarsus Kieffer (Diptera: Chironomidae) with description of three new species. Polish Journal of Entomology 70: 307-328.

GEKA W. 2002. Tanytarsini (Diptera: Chironomidae) of Poland - a faunistic review. Polish Journal of Entomology 71 : $415-428$.

GÆKA W. 2006. A hundredth species of the tribe Tanytarsini in the Polish fauna. Dipteron 22: 8-10. [In Polish with English abstract]

GLKA W. 2007. A faunistic review of chironomids of the tribe Tanytarsini (Diptera: Chironomidae) of the Tatra National Park. Dipteron 23: 11-17. [In Polish with English abstract]

GEKA W. 2009. New and rare chironomids of the tribe Tanytarsini in Poland (Diptera: Chironomidae). Polish Journal of Entomology 78: 377-384.

GÆKA W. \& DOMINLAK P. 2007. Tanytarsini (Diptera: Chironomidae) of the Kashubian Lakeland. Fragmenta Faunistica 50: 47-55.

KOWNACKI A. 1982. Stream ecosystems in mountain grassland (West Carpathians) 8. Benthic invertebrates. Acta Hydrobiologica 24: 375-390.

LEHMANN J. 1970. Revision der europäischen Arten (Imagines $\delta \delta$ und Puppen $\delta \delta$ ) der Gattung Rheotanytarsus BAUSE (Diptera, Chironomidae). Zoologischer Anzeiger 185: 344-378.

PLIŃSKI M. \& WNOROWSKI T. 1993. The plant communities of lake Żarnowiec and its flood zone during the initial operation of the pumped-storage power stadion. Wydawnictwo Uniwersytetu Gdańskiego, $130 \mathrm{pp}$.[In Polish with English summary]

REISS F. \& FITTKAU E. J. 1971. Taxonomie und Ökologie europäisch verbreiteter Tanytarsus-Arten (Chironomidae, Diptera). Archiv für Hydrobiologie, Suppl. 40, 75-200.

REISS F. \& SÄWEDAL L. 1981. Key to males and pupae of Palearctic (exl. Japan) Paratanytarsus Thienemann, Bause 1913 n. comb., with description of three new species (Diptera, Chironomidae). Entomologica scandinavica, Suppl. 15: $73-104$.

SETHER O. A. \& SPIES M. 2004. Chironomidae. In: Fauna Europaea Service, Fauna Europaea version 1.3. Internet data base available online: http://www.faunaeur.org (accessed: 29 March 2009).

SÄWEDAL L. 1976. Revision of the notescens-group of the genus Micropsectra Kieffer, 1909 (Diptera: Chironomidae) Entomologica scandinavica 7: 109-144.

SowA R. 1965. Ecological characteristics of the bottom fauna of the Wielka Puszcza stream. Acta Hydrobiologica, Suppl. 7:61-92.

STUR E. \& EKREM T. 2006. A revision of West Palaearctic species of the Micropsectra atrofasciata species group (Diptera: Chironomidae). Zoological Journal of the Linnean Society 146: 165-225.

WIŚNIEWOLSKI W. \& MALINOWSKI R. 2004. Oddziaływania elektrowni wodnej „Żarnowiec” na ekosystem jeziora Żarnowieckiego ze szczególnym uwzględnieniem wpływu na ichtiofaunę. Uzupełnienie. [Opinion] Elektrownia Wodna Żarnowiec S.A., Czymanów, 35 pp

\section{STRESZCZENIE}

\section{[Spadek różnorodności faunistycznej w zaburzonym środowisku Jeziora Żarnowieckiego na przykladzie ochotkow atych z plemienia Tanytarsini (Diptera: Chironomidae)]}

Prezentowana analiza objęła muchówki z rodziny ochotkowatych i plemienia Tanytarsini (Diptera: Chironomidae), grupę hydrobioindykatorów o zróżnicowanej tolerancji. Material zebrano nad Jeziorem Żarnowieckim na początku lat 80-tych oraz w latach 2008 i 2009. Zestawienie uzyskanych wyników wskazuje na wyraźne ubożenie fauny jeziora. Liczba gatunków Tanytarsini notowanych w okresie niespelna 30 lat spadła z 21 do 14. Faune zdominowaly pospolite gatunki eurytopowe: Cladotanytarsus atridorsum Kieffer (ponad 73\% okazów zebranych w 2008 r.), C. mancus (Walker) (ponad 8\%), Paratanytarsus inopertus (Walker) (ponad 9\%), natomiast czterech rzadkich gatunków, notowanych na badanym obszarze w latach 80-tych, obecnie nie stwierdzono (Tanytarsus niger Andersen, Rheotanytarsus muscicola Thienemann, Stempellinella brevis (Edwards), Paratanytarsus tenellulus (Goetghebuer)). Spadek bioróżnorodności Tanytarsini zinterpretowano jako skutek niestabilnych parametrów jeziora, sztucznie uregulowanego na potrzeby elektrowni szczytowopompowej „Żarnowiec" w 1983 roku, a także inwestycji związanych z budową elektrowni jądrowej, wdrażanych w latach 80-tych. 